\title{
ВЫЗЫВАНИЕ ДОМОВОГО В ДЕТСКОЙ ИГРОВОЙ ТРАДИЦИИ КОМИ
}

\author{
Алексей Рассыхаев \\ rassyhaev@mail.ru
}

Аннотация: В статье рассматривается уникальная для традиционной духовной культуры коми детская игра в вызывание домового. Приведены новые аутентичные тексты, а также ранее не привлекавшиеся архивные материалы. Их анализ позволяет расширить границы распространения забавы. Судя по новым источникам, она бытовала не только у коми бассейна р. Вычегда (с притоками Вишера, Вымь и Сысола), но и у северных коми-пермяков в косинской традиции. Игры схожи по сценарию и направлены на установку контакта с невидимым обитателем подполья и проверку его существования. Наибольшая вариативность проявляется в наименованиях демонима, поэтических обращениях к нему и характеристике. В образе и терминологии «игрового» домового отражаются мифологические представления, схожие с «фольклором взрослых», однако обращения к вызываемому персонажу часто приобретают черты «детскости» - уменьшительно-ласкательные суфрфиксы, приём редупликации, личные имена. С точки зрения коллективного испытания чувства страха игра близка к магически-игровым вызываниям персонажей неомифотворчества (Пиковой Дамы, Гномика, Чертей и т. д.), распространённым среди современных школьников, в т. ч. и коми.

Ключевые слова: фольклор коми, коми-пермяцкий фольклор, детская игра, мифология, игровая терминология, домовой 


\section{Введение}

Специфической для народной культуры коми является детская игра в вызывание домового из голбца. В научной литературе за ней закрепилось два названия: Юрий Рочев условно называет игру гӧбӧч айка 'дух голбца' (исследователь переводит название как "хозяин подполья») (Рочев 1972: 135; Рочев 1979: 219), Дмитрий Несанелис - гӧрд гача (букв. 'в красных штанах') (Несанелис 1994: 95).

Игра была предметом отдельного исследования Д. Несанелиса, рассмотревшего её в этносемиотическом ракурсе в статье «Старинная игра детей коми “гӧрд гача": опыт семантического анализа» (Несанелис 1989). Автор анализирует значимые черты персонажа, вызываемого детьми из подполья, такие как сравниваемая с глиной мягкотелость, негативно воспринимаемая красная окраска его тела и одежды (штанов), пестрота, которые, по мнению исследователя, позволяют сблизить его с мифологическим «первочеловеком». В ходе игры дети актуализируют представления о пространственной оппозиции низа и верха (домовой в подполье), противопоставлении чужого и своего, мира предков и мира живых, хаоса и космоса. Соглашаясь со многими позициями исследования, тем не менее, попытаемся обратить внимание на фокты, до сих пор не затронутые. Также, приведём аутентичные тексты, записанные в последние десятилетия, и расширим географию распространения данной игры.

\section{Описание игры}

$\mathrm{C}$ точки зрения типологии, игру можно назвать забавой или игрой-импровизацией, т. к. она проходит без специальных правил, по которым строится большинство игр выбора водящего, наказания проигравшего игрока и пр.

Первое известное описание этой игры было сделано в конце XIX в. учеником Вологодской духовной семинарии Леонидом Каплиным, зафиксировавшим бытование игры в верхневычегодском с. Деревянск: 
Собираются в один дом несколько парней, закрывают окна, чтобы было темно. Все садятся на лавки и поднимают ноги, чтобы косой или серпом не отсек их домовой. Двери голбца отворяют настежь. Один парень стоит у входа на стуле с клюкой и говорит, ударяя клюкою о стул: «Суседушка-братушка, пет же, пет же и видль миянльсь сов, ва, няньсӧ 'Суседушка-братушка, выходи же, выходи же и попробуй нашу воду, хлеб и соль'». В это время по половишникам прокатывается домовой в виде куриного яйца. Немного подождавши, открывают сразу окна и все бегут смотреть, домовой или нет. Если бросить в яйцо (домового) поленом, то посыпется очень много золота и серебра ${ }^{1}$ (Каплин 1898: 4).

Л. Каплин в своей работе приводит и другое наименование домового - виж кок 'жёлтая нога', зафиксированное в дер. Весляна (коми Весььва) на р. Вымь (ныне - Княжпогостский р-н). В начале игры дети закрывали окна, а перед входом в голбец втыкали нож (Каплин 1898: 16).

Второе по хронологии описание игры принадлежит студентке Коми пединститута А. Е. Агафоновой, записавшей в 1935 г. в Сыктывкаре игру под названием орт петкӧдӧл 'вынос душиopm '2. Дети занавешивали окна, к дверям голбца выкладывали воду и хлеб и все вместе обращались к домовому:

Гӧбӧч ульсь пачсай айка,

Петав жӧ, петав,

Выс няньӧн вердал,

Пань тыр ваӧн юкталал. ${ }^{3}$

Из-под голбца запечный дух, Выйди же, выйди, Хлебом с маслом накормим, Ложкой воды напоим!

В комментарии к игре отмечено, что, вызывая домового, игроки порой теряли от страха сознание.

Из иных описаний игры известно, что она проходит летом (в сенокосную страду) в отсутствие взрослых. Закрыв окна в доме и положив у входа в голбец хлеб с солью и воду, дети берут в руки кочергу и залезают на печку, с которой вызывают «сюседушкубратанушку» ${ }^{4}$ (Образцы 1971: 72-73). В других вариантах игры дети поднимаются на полати, сундуки, лавочки, в руки берут ножницы, нож, палку, пест или ухват: 
Тупкалам ӧшиньяс, укват босьтал, да уквата мортіс каяс лабиче, а мукедіс ворсэні джоджин. Ставніс шувалэні:

Пи-пи тойин, петаллі, Ива Шорлэн нянис кылэ, Поплэн нянис сотче! Ӧшиньтэ костэдіштаснь и югидіс югдэдас, сэк горедал: "nu-nu тойин петэ!" Эсся ставен пышъял, полал да.
Закроем окна, возьмём ухват, и человек с ухватом встанет на лавочку, а остальные играют на полу. Все говорят: Пu-nu' пест, выйди-ка, У Ива Шора ${ }^{7}$ хлебом пахнет, У попа хлеб горит!

Окно <занавеску> приоткроют, и луч осветит, тогда крикнем: «пи-nu пест выходит!» Потом все убежим, потому что боимся.

В некоторых вариантах игры один из участников (старший по возрасту и опытней) предварительно заходит в голбец, из которого выходит после исполнения приговорки. В нашем распоряжении имеется более 20 описаний данной игры, сценарий которых практически не отличается от вышеприведённых.

\section{Распространение игры}

Согласно публикациям Ю. Рочева и Д. Несанелиса, география бытования игры в вызывание домового из голбца ограничивается тремя районами Республики Коми - Усть-Вымским, УстьКуломским и Сыктывдинским. Анализ архивных источников и экспедиционные исследования позволили расширить границы распространения игры по р. Вычегда (коми Эжва) (с притоками Вишера (Висер), Вымь (Елва) и Сысола (Сьютыьв)), где она была зафиксирована в следующих населённых пунктах: дер. Весляна Княжпогостского р-на; с. Усть-Вымь (Елдін) Усть-Вымского p-на; селах Озёл и Пажга (Паджга) Сыктывдинского р-на; г. Сыктывкаре; сёлах Куратово (Куратов) и Межадор Сысольского р-на; сёлах Большелуг (Ыджыдвидз), Важкуръя (Важкуа)

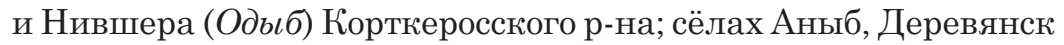
(Дереваннӧй), Дон, Керчомъя, Нижний Воч (Ульс Воч), Пожег (Пожӧг), Помоздино (Полӧсдін), Усть-Кулом (Кулӧмдін) УстьКуломского р-на. 
Кроме этого, во время проведения экспедиционных исследований у коми-пермяков, проживающих в Коми-Пермяцком округе Пермского края, в 2011 г. автором данной работы была зафиксирована аналогичная игра в деревнях Чураки и Пуксиб Косинского района ${ }^{8}$. Приведём описание одного из вариантов игры в «Суседушко» (суседушкоьсь орсльллілӧ), записанное в дер. Чураки:

Няньыс эл дак, картокаторрез да няньторрез пуктан, крӧшитан бекӧрӧ да, джоджуллэз вӧллісӧ, осьтан да, сія джоджулсӧ осьтан, сэтчин мыйкӧ вылас, пуктан лабич вылас, и босьтан укват ли заступ ли и сійӧн керку гӧгӧрат [нрзб]:

Суседушко-вартанушко!

Хлебушко да соль,

Ми тэд пуктіл.

Миянль бурджыка кер!

Сія ешшё сольщттан дак. Сія кыскан - дак сэтшӧл чӧскьљ! Сусеткуыц сія сэтчӧ солалас сэсся. Ӧддьӧн сійӧн мырддьысям да сёял. [...] А кор нянььц вӧлі, сэки и орсал, кор окота сёйнь ${ }^{9}$.
Если хлеб есть, картошку и хлеб положишь, покрошишь в тарелку, раньше [в домах] были подполья, откроешь, подполье откроешь, и туда на лавочку поставишь, и возьмёшь ухват или заступ, и им по всему дому [ударяешь]:

Суседушко-вартанушко!

Хлебушко да соль,

Мы тебе положили.

Нам получше сделай!

Ещё посолишь <хлеб>. Его достанешь - так такой вкусный! Cусетку этот там посолит. Потом отнимаем друг у друга, и едим. [...] А когда хлеб был, тогда и играем, когда охота поесть.

Бытование подобной игры у коми-пермяков отмечено впервые. Факт записи у коми-пермяков расширяет ареал распространения детской игры в вызывание домового и позволяет говорить о возможном существовании контактной зоны в районе Верхней Вычегды и Верхней Камы. Косинский р-н Пермского края в северной части граничит с южными населёнными пунктами УстьКуломского р-на Республики Коми, в которых анализируемая игра, судя по собранным материалам, получает наибольшее развитие. 


\section{Терминология}

Рассматриваемая игра известна под различными названиями, основным отличительным элементом которых является наименование вызываемого домового. Имя мифологического персонажа фригурирует преимущественно в поэтических обращениях к нему. В игровых приговорках некоторые из наименований образованы от русских слов - демонимов дед и суседко с присоединением уменьшительно-ласкательных суффриксов и зарифмованных парным словом: суседушка-братанушко (с. Деревянск), соседушко-воседушко (с. Аныб), дедушка-бедушка (с. Усть-Кулом), дедӧ-бедӧ, дедушко-бедушко (с. Большелуг), дедушко (с. Пажга). В этом же ряду следует рассматривать семантически дублированное дедё-пӧльӧ (пӧльӧ 'отец отца, дедушка') (сёла Куратово и Межадор). Стоит отметить, что обращения суседушко и дед также используются в различных приговорах, применяемых в скотоводческой обрядности коми.

В верхневычегодских вариантах зафиксированы названия, вторая часть которых представлена словом тоин 'пест'. Первая же часть иногда озаумлена, однако с некоторой долей вероятности ее можно этимологизировать: пuny тоин 'осиновый пест' (сёла Пожег, Нижний Воч, Помоздино); пи-пи тойин (Пожег, Важкуръя), пu-nu - произошла десемантизация слова пuny; припетойин (Керчомъя), припе - десемантизация исходного nuny. Не исключено, что раньше материалом для изготовления песта служила осина, что и отразилось в игровом наименовании домового. Примечательно, что, по словам одного из информантов, necm 'тоин' используется в качестве игрового атрибута:

Сыа гӧлбӧчтӧ йигналан вӧлі. Сәсся занавесалан ӧшиньяснылиӧс. Сэсся челядь чукарыљ босьтан мыцйкӧ, этія гырйын тойин выйил, да кералан:

Припетойин, петжё, пет, Сера кычи, эн жӧ пет! ${ }^{10}$
Голбец запирали. Потом занавешивали окна. Потом дети брали, в этой ступе есть пест, и ударяли им:

Припе necm, выйди же, выйди, Пёстрый щенок, уж не выйди! 
В ряде названий дана окраска и характеристика вызываемого из голбца персонажа: шыра-каня, матушка 'мышь с кошкой, матушка' (с. Дон), кос петук 'сухой петушок' (с. Озёл), виж кок 'жёлтая нога' (дер. Весляна), гӧрд косаа 'с красной косой', гӧрд гача 'красноштанный', гӧбӧч айка 'дух голбца' (г. Сыктывкар).

В некоторых случаях домовой получает человеческое имя, которым пугают непослушных детей: чурка Микипер 'незаконнорождённый Никифор’ (с. Нижний Воч), чилля Ёгор 'Егор с пенисом' (с. Помоздино).

В коми-пермяцких вариантах игры к домовому обращаются как к суседушко-вартанушко (дер. Чураки) или сюсю-баба (дер. Пуксиб). Возможно, редупликат вартанушко происходит от вартан - молотильный цеп; то, чем ударяют во время вызывания домового, создавая шумовой эфрфект; или от братанушко (ср. зафиксированный в с. Деревянск демоним суседушкабратанушко). Можно предположить, что сюсю есть усечённая основа слов суседушко или сусетку, которым называют мифологического персонажа в косинской фольклорной традиции. Примечателен ответ информанта на вопрос "A кто такой Сюсю-баба?»- «А сусеткуыс! Сусетку сія. А мый нӧ, орсіканыли бара Сюсю-бабаӧн шуали' 'А сусетку. Сусетку это. А в игре его называем Сюсю-баба'11.

Между тем, в игровых обращениях не встречаются следующие наименования персонажа, распространённые в фольклорных традициях, в которых бытовала игра в вызывание домового: бубыля (г. Сыктывкар), бубиля (села Деревянск, Керчомъя) ${ }^{12}$, бубуля (г. Сыктывкар), бубуня (Средняя Сысола), буба (с. Богородск) (ССКЗД 1961: 28); олься, оліся, ольсь 'живущий; житель' (ССКЗД 1961: 259); керка видзысь 'дом охраняющий'.

Рассмотрев наименования домового, используемые в играх, можно предположить, что запрет на прямое называние мифологического персонажа связан с ослаблением детского страха перед неизведанным и необъяснимым, созданием ситуации, максимально благоприятной для контакта с потусторонними силами. 


\section{Мифологические мотивы игры}

В игре вызывания домового содержится ряд архаических представлений, о чём уже было отмечено ранее (см. Несанелис 1989). Тем не менее, в рамках данной работы мы укажем на иные мифологические мотивы, связанные с традициями коми. Для установления благоприятных условий контактирования с духом подполья игроками вносятся изменения в помещении: в крестьянской избе занавешивают окна, создавая полумрак как наиболее подходящую обстановку для встречи с потусторонними силами:

Ӧшиньяссӧ тупкалал, асьніл пӧлате кая.м. Кодi бедь босьтас, коді пурт, кокалюкаяс, ся горзал: Koc nemyк, nem, nem! ${ }^{13}$
Окна закроем, сами на полати поднимемся. Кто палку возьмёт, кто - нож, кочергу, потом кричим: Сухой / Худой петух, выходи, выходи!

Дети вносят в игровой процесс деструктивные моменты, характерные для иных ритуальных и переходных календарных и жизненных ситуаций: переворачивают иконы в божнице, как и во время гаданий (Семенов 1991: 65); выворачивают наизнанку шубу или одевают одежду похуже, подобно святочным ряженым (Несанелис 1994: 56):

Вӧльь ӧшиньяс тупкаласны, ен гугӧдасны да гугапасясясньь, да кодкӧ пьюрас гӧбӧчӧ, да вӧльь шуалал:

Дедушко-бедушко, петов тэ, nетов! $!^{14}$
Окна занавешивали, иконы переворачивали да надевали шубу наизнанку, и кто-то зайдёт в голбец, и мы говорили:

Дедушко-бедушко, выходи же, выходи! 
Для установления контакта с домовым подключается также звуковой код - игроки ударяют пестом, кочергой, ухватом, палкой или веретеном по полу, дверям голбца, клацают ножницами и бегают на кочерге по полу:

Сувталасны, ӧтик босьтас коколюка кок вож костас котравны джодж кузяьс:

Чилля Ёгор, петалльи, Чилля Ёгор, петалль!!

И сійӧ ноксигкост тіыс чӧвтасны гӧбӧчас коколюкасӧ и ставыс котӧртасньь-каяснь паччӧрас. ${ }^{15}$
Встанут, один возьмёт промеж ног кочергу и будет бегать по полу: Чилля Ёгор, выйди-ка! Чилля Ёгор, выйди-ка! И во время беготни забросят кочергу в голбец и все побегут - поднимутся на лежанку печи.

Приглашение домового отведать приготовленную еду (вода пресная и соленая, соль, хлеб с маслом, картошка) вполне сопоставима с актом кормления «родителей» (умерших предков) по утрам в доме или в поминальные дни на кладбище. Кроме обращения к домовому выйти из подполья и просьбы попробовать пищу (в одном тексте - скосить траву на пастбище), в некоторых игровых приговорках звучат условия и угрозы в адрес духа голбца за неподчинение требованиям играющих:

Суседушка-братанушка,

Чеччыв жӧ, чеччыв!

Суседушка-братанушка,

Петав жӧ, петав!

Он кӧ петав,

Кӧрт коколен клёнӧдал, клёнӧдали.

Петалан кӧ,

Мича паньӧн паньӧдал, паньӧдали,

Вый паньӧн паньӧдам, паньӧдал. ${ }^{16}$
Суседушка-братанушка,

Встань же, встань!

Суседушка-братанушка, Выйди же, выйди!

Если не выйдешь, Железной клюкой поколотим, поколотим.

Если выйдешь,

Красивой ложкой накормим, накормим, Ложкой масла накормим, накормим. 
Вызывание домового из голбца сопровождается коллективным переживанием страха, проверкой наличия локуса нижнего мира и его обитателя:

Эсся ставныл ланьтлал. Видзӧдал - эз на пет, оз пет. Куимысь кылын сььллал. Сэсся кодкӧ и ӧти горӧдас - петіс пӧ. Сэсся сія и повзыьссяс дзӧляасьд. Господи! O-о-й, сэсся сія ставыс кутан дзебсььныь. «Oй-ой, nemic, oŭ-oŭ, nemic». Ӧти юалӧ: «Кутшел?» Дзӧляясыд: «Кутшел?»«Югыд синла!! - «Сюра абу?» Да ӧд колӧ жӧ вӧлі челядьсӧ повзьӧдлььны тайӧн! ${ }^{17}$
Потом все замолкнем. Смотрим - ещё не вышел, не выходит. Трижды примерно споём. Потом кто-то один и крикнет - вышел, мол. Потом и малыши испугаются. Господи! Ой, потом все начинают прятаться. «Ойой, вышел, ой-ой, вышел». Один спрашивает: «Какой?» Малыши: «Какой?» « блестящими глазами!» «С рогами?» Да ведь нужно же было детей пугать этим!

По мнению Д. Несанелиса, «в локализации домового (подполье) и играющих детей (полати) отчётливо отразились представления о пространственной оппозиции низа и верха. Если у взрослых представления о вертикальной структуре жилища раскрывались, главным образом, в строительной обрядности, то у детей они актуализировались в ходе игры» (Несанелис 1994: 104-105). Таким образом, в игровой форме дети усваивают основы вертикального и горизонтального членения пространства.

В процессе игры дети, с одной стороны, заигрывают с домовым, вызывая из голбца, а с другой - остерегаются встречи с ним. Подобное поведение характерно для игровых ситуаций, когда участники игры дразнят, одурачивают, вводят в заблуждение водящего, наделённого чертами мифологических персонажей (одноногость, слепота, способность к обездвижению, перемещение вихрем), и в то же время боятся быть пойманными им (Рассыхаев 2014: 108-109). 
В игровых приговорках содержится имя демонима и его основные характеристики и атрибуты - в красных штанах, с косой, блестящими глазами, пестрота. К примеру, в керчомских вариантах приговорки (верхневычегодская традиция) играющие запрещают выходить пёстрому щенку сера кычи из голбца. Нам представляется, что в этом случае данное домашнее животное является одним из ипостасей самого мифологического персонажа. В русском фольклоре домовой также иногда показывается людям в образе собаки. В качестве примера можно привести текст из соседней с коми русской традиции: "(Какой он из себя?) Она [бабушка-нянька] говорила, что вот, блестит, как собака такая. А где, какая она? Мы не видали». ${ }^{18}$

Несомненно, в игровом образе домового переплелись как мифологические практики взрослых, так и детские суждения о невидимом духе. Можно предположить, что представления детей о персонаже низшей мифологии основываются также на традиционных запугиваниях домовым. Подобные запугивания имеют воспитательную направленность и призваны уберечь детей от травм, которые можно получить, упав в подполье. Голбец был не только местом хранения продуктов питания (хлеба, выпечки, картошки и т. п.), но и местом повышенной опасности для малышей.

В некоторых традициях вызывание духа подполья трансформировалось в запугивание детей. Информант из с. Большелуг вспомнила детские годы, когда однажды зимним днём их внезапно пригласили в соседний дом вызывать дедӧ-бедӧ и попросили подняться на полати. После окликания из подполья вышло чудовище в лохмотьях, шапке и с бородой, наводившее страх на всех ребят. Спустя некоторое время дети узнали в чудовище соседскую девушку. Они считали, что если домовой поймает детей, то они навсегда заснут. ${ }^{19}$

Игра в вызывание домового была вытеснена из игрового репертуара в послевоенные годы, но окончательное забвение игры у коми произошло в 1970-х гг. Следующая стадия бытования детской забавы в вызывание домового - переход в игру по правилам. В нынешнее время рассказывают лишь истории о том, как играли в эту игру раньше. $\mathrm{K}$ примеру, студентка 
Сыктывкарского государственного университета следующим образом описывает игру со слов своей бабушки (ьљжыд мал):

Ная челядь чукӧр чукӧртчасны керкаас, кодлӧн ьљжыдәясыс абуӧсь. Сэсся занавесъяссӧ ставсӧ вешталасны, мед пельд вӧлі керкаас. Эсся кутшӧлкӧ лортӧс, но тоже пудбясяснь, ӧти мортӧс пасьтӧдасны гӧна пасьӧн, и пырас сійӧ гӧбӧчӧ. Эсся гӧбӧчсӧ сиптасны. Сэсся сэн лыйкӧ шаланитасны, ог тӧд, мыцйкӧ шуаласньь, шуаласньь. И сійӧ кор петӧ, сійӧ, сэн жӧ ичӧт челядь тшйтш ворсӧны, ичӧт челядыьс пӧ зэв ёна вӧлі бӧрдӧны и котралӧны керка пасьталаас. И этія, кодӧс пӧ суас, сійӧс пӧ вӧлі гӧбӧчас и пьюттас. Чукӧртӧ ӧтикан. Сэсся коді кольӧ, сэсся сійӧ гӧна пасьнас пасьтасьӧ. ${ }^{20}$
Они, детвора, соберутся в доме того, у кого взрослых нет [дома]. Потом все занавески задвинут, чтобы темно было в доме. Потом одного человека, тоже жребий бросят, одного человека в мохнатую шубу оденут, и он зайдёт в голбец. Потом голбец закроют. Потом там что-то пошаманят, не знаю, что-то приговаривают. И когда он выходит, с ними маленькие детки тоже играют, и, мол, малыши очень сильно плакали и бегали по дому. И это, мол, кого догонит, того и в голбец заведёт. Собирает по одному. Потом кто останется, тот и наденет мохнатую шубу.

C точки зрения коллективного испытания чувства страха, рассматриваемая игра близка с магически-игровыми вызываниями персонажей неомифотворчества (Пиковой Дамы, Гномика, Чертей и т. д.), распространёнными среди современных школьников, в т. ч. коми. Для участников "ритуала», также происходящего в темноте и без присутствия взрослых, важно установить через зеркало связь со сверхъестественными существами и обнаружить следы их присутствия в помещении (Новицкая \& Райкова 2002: 44). От вызываний домового в коми традиции они отличаются загадыванием желания, своеобразным гипнотическим сеансом, заканчивающимся разбиванием зеркала или захоронением. 


\section{Игровая приговорка}

В каждом описании игры присутствует вербальное сопровождение, состоящее из поэтического обращения к домовому и призывов к нему: выйти к играющим, отведать пищу - хлеб с маслом или солью, воду.

Несмотря на то, что в некоторых описаниях игры информанты используют лексику, указывающую на коллективное пение этих строк (челядь артельӧн сьылӧны 'дети хором поют'; а сьылал тайӧ 'а поём вот это'; пондали сьььны челядь чукар 'мы, ватага детей, начинаем петь'), в комментариях чаще речь идёт о проговаривании: ставніс шувалэні 'все говорят', дедушкоӧс корил 'дедушко позвали', челядьдырйи шуліл 'в детстве говорили', войдӧр вӧлі чуксалласны 'раньше вызывали', ся горзал 'потом орём'. Причем один и тот же информант может употреблять лексику, указывающую на проговаривание и пение:

Сэсся тай кутан шунь::

Суседушка-вӧседушка, Чилье-чилье, петав, петав! [...] Тая вӧлі сььланкывълсьљ, век вӧлі сьььлӧньь. ${ }^{21}$
Потом начнёшь говорить:

Суседушка-воседушка, Чилье-чилье, выйди, выйди! [...] Вот эти были песни, всегда пели.

Неопределённость с манерой исполнения текстов подтверждают мысль Александра Белоусова об отсутствии в народной культуре чёткого разграничения между игровыми припевками и игровыми приговорками и дифрфузии текстов: «один и тот же текст может существовать как в виде “припевки”, так и в виде “стишка” / “приговорки”» (Белоусов 1989: 12). 


\section{Выводы}

Анализ приведённых в работе описаний игр в вызывание домового в коми традиции позволяет расширить границы бытования забавы. Она была распространена не только у коми бассейна Вычегды (с притоками Вишера, Вымь и Сысола), но и у северных коми-пермяков в косинской традиции. Игра является уникальной, не имеющей аналогов в традициях других народов. В образе и терминологии «игрового» домового отражаются представления, схожие с «рольклором взрослых», однако обращения часто приобретают «детскость» (уменьшительно-ласкательные суффиксы, приём редупликации, личные имена). В игровой форме дети актуализируют многие онтологические представления о природе страха, сущности мифологического персонажа, бинарной оппозиции свой-чужой, вертикальной структуре пространства.

\section{Сокращения}

НА Коми НЦ - Научный архив Коми научного центра УрО РАН

НМРК - Национальный музей Республики Коми

ПМА - полевые материалы автора

ФА СыктГУ - Фольклорный архив Сыктывкарского государственного университета 


\section{Примечания}

1 Любопытно, что в «игре» вместо детей участвуют парни, а мифологические представления о домовом, приносящем золото или серебро, находят устойчивые параллели в суеверной русской прозе. К примеру, в пос. Нючпас Койгородского р-на Республики Коми от потомков русских, переселившихся из Вологодской, Вятской и Костромской губерний, записано поверье о том, что если задеть домового, то посыпется серебро или золото (Лобанова \& Низовцева \& Рассыхаев 2011: 27, 41):

Вот у нас Шевелиха бабушка была. Она нас настращает - мьь этот, боимся выйти. "Ой, говорит, сейчас вот придёт этот, какой-то, говорит, вышел ... (Как она и говорила...?) доловой, да его заденешь да, говорит, посыплются золото". Мы ищел, ходил везде. Ни у кого нету долового, нигде. (Зап. А. Н. Рассыхаев 04.06.2011 г. в пос. Нючпас Койгородского р-на РК от Галины Николаевны Михайловой, 1928 г. р. (ПМА))

2 Opm - мифологический дух-двойник человека (Рочев 1985).

3 Зап. А. Е. Агафонова в 1935 г. в Сыктывкаре (НМРК: КП-12484. Л. 157 об.).

4 Зап. Е. С. Гуляев в 1963 г. в с. Деревянск Усть-Куломского р-на.

5 Зап. М. А. Сахарова 26.03.1963 г. в с. Пожег Усть-Куломского р-на от Парасковьи Павловны Лужиковой (НА Коми НЦ: Ф. 1. Оп. 11. Д. 227. Л. 204).

6 Пu-nu-возможно, произошла десемантизация слова пuny 'осина'.

7 Ива Шор - в данном контексте может означать прозвище односельчанина.

8 За консультацию по коми-пермяцкой диалектологии выражаю искреннюю благодарность научному сотруднику ИЯЛИ Коми НЦ Елене Николаевне Федосеевой.

9 Зап. А. Н. Рассыхаев 16.07.2011 г. в дер. Чураки Косинского р-на КПО Пермского края от Веры Васильевны Федосеевой, 1928 г. р., уроженки дер. Чураки (ПМА).

10 Зап. Ю. Г. Рочев в июне 1977 г. в с. Керчомъя Усть-Куломского р-на от Э. Ф. Тарабукиной, 1930 г. р. (НА Коми НЦ: Ф. 5. Оп. 2. Д. 218 а. Л. 191. № 80. Л. 191). 
11 Зап. А. Н. Рассыхаев 17.07.2011 г. в дер. Пуксиб Косинского р-на КПО Пермского края от Неонилы Семеновны Федосеевой, 1932 г. р., уроженки дер. Пуксиб (ПМА).

${ }^{12}$ Исключение составляет одно описание игры из с. Керчомъя УстьКуломского р-на: домового вызывают со словами Сера бубыль, nem, nem, nem! 'Пестрая бубыля, выходи, выходи!' (ЭД 1999: № 98).

13 Зап. Н. И. Лоскутова \& Г. Г. Бараксанов 08.12.1965 г. в с. Озел Сыктывдинского р-на от Калисы Ивановны Лыткиной, 1898 г. р. (НА Коми НЦ: Ф. 1. Оп. 11. Д. 264. Л. 131).

14 Зап. в 1995 г. в дер. Мале Пожегодского с/с Усть-Куломского р-на от Николая Степановича Мартюшева, 1938 г. р. (ФА СыктГУ: 1213-3).

15 Зап. в с. Помоздино Усть-Куломского р-на от Поликсении Васильевны Игнатовой, 1921 г. р. (ФА СыктГУ 1214-19).

16 Зап. Ю. Г. Рочев в июне 1977 г. в с. Деревянск Усть-Куломского p-на от И. А. Гуляевой, 1910 г. р. (НА Коми НЦ: Ф. 5. Оп. 2. Д. 218 а. Л. 212. № 88).

17 Зап. Ю. Г. Рочев в июне 1977 г. в с. Деревянск Усть-Куломского р-на от И. А. Гуляевой, 1910 г. р. (НА Коми НЦ: Ф. 5. Оп. 2. Д. 218 а. Л. 212-213. № 88).

18 Зап. А. Н. Рассыхаев 04.06.2011 в пос. Нючпас Койгородского р-на РК от Галины Николаевны Михайловой, 1928 г. р. (ПМА).

19 Зап. А. Н. Рассыхаев 16.06.2015 в с. Большелуг Корткеросского р-на от Лидии Михайловны Габовой, 1927 г. р. (ПМА).

20 Зап. А. Н. Рассыхаев 20.12.2013 в г. Сыктывкар от Лодыгиной Виктории Сергеевны, 1995 г. р., уроженки с. Керчомъя Усть-Куломского р-на (ПМА).

21 Зап. Ю. Г. Рочев в июне 1977 г. в с. Аныб Усть-Куломского р-на от А. Д. Панюковой, 1894 г. р. (НА Коми НЦ: Ф. 5. Оп. 2. Д. 218 а. Л. 308. № 145). 


\section{Литература}

Белоусов, Александр 1989. Детский фольклор. Лекиия для студентовзаочников. Таллинн.

Каплин, Леонид 1898. Описание обычаев и нравов народа коли (села Деревянск на реке Вычегде Усть-Сысольского у.). - Вологодский государственный архив. Ф. 883. Оп. 1. Д. 182. 32 л. Цит. по: Несанелис, Дмитрий 1999. Детские игры. - Этнографическая электронная энциклопедия «Традиционная культура народов Европейского Северо-Востока России»; http://www.komi.com/FOLK/KOMI/138.htm.

Лобанова, Людмила \& Низовцева, Светлана \& Рассыхаев, Алексей 2011. Отчёт о полевых исследованиях фбольклорных экспедииий в пос. Нючпас Койгородского района и пос. Нювчим Сыктывдинского района Республики Коми в 2011 году. Сыктывкар, 2014. Научный архив Коми НЦ: Ф. 5. Оп. 2. Д. 804.92 л.

Несанелис, Дмитрий 1989. Старинная игра детей коми "гӧрд гача»: опыт семантического анализа. - Генезис и эволющия традиционной культуры коми. Труды ИЯЛИ Коми НЦ УрО РАН. Вып. 43. Сыктывкар, 80-89.

Несанелис, Дмитрий 1994. Раскачаели мы ходкую качель. Традииионные фбормы досуга сельского населения Коми края (Вторая пол. ХІХпервая треть XX вв.). Сыктывкар, 168.

Новицкая, Марина \& Райкова, Ирина 2002. Детский фольклор и мир детства. - Новицкая, Марина \& Райкова, Ирина (сост., вступ. статья, подгот. текстов, коммент.). Детский фбольклор. Библиотека русского фольклора. Т. 13. Москва: Русская книга, 5-53.

Образцы 1971 = Сорвачёва, Валентина \& Жилина, Татьяна (сост.). Образиы коми-зырянской речи. Сыктывкар.

Рассыхаев, Алексей 2014. Детский игровой фбольклор коли: жанровый аспект. Сыктывкар.

Рочев, Юрий 1972. Детский фольклор коли: Дисс. на соискание учёной степени к. фбилол. н. - НА Коми НЦ. Ф. 5. Оп. 2. Д. 129. 182 л.

Рочев, Юрий 1979. Детский фольклор коми. - История коми литературы. Т. 1. Сыктывкар, 195-224. 
Рочев, Юрий 1985. Традиционные представления коми об орте и их трансформация в современности. - Традиция и совреленность в культуре сельского населения Коми АССР. Труды Института языка, литературы и истории Коми филиала Академии наук СССР. Вып. 37. Сыктывкар, 57-70.

Семёнов, Виктор 1991. Традииионная духовная культура коли-зырян: Ритуал и символ: Учебное пособие. Сыктывкар.

ССКЗД 1961 = Жилина, Татьяна \& Сахарова, Марфа \& Сорвачёва, Валентина (сост.). Сравнительный словарь коми-зырянских диалектов. Сыктывкар.

ЭД 1999 = Панюков, Анатолий \& Савельева, Галина (сост.). Традиционная культура коми: Этнографбия детства. Материальь фбольклорно-этнографбических экспедиций 1995-1998гг. Сыктывкар. 


\section{ФОЛЬКЛОРИСТИКА КОМИ: исследования и материалы}

\section{http://www.folklore.ee/rl/pubte/ee/sator/sator17/}

ISSN 1736-0323

ISBN 978-9949-586-24-0

DOI: $10.7592 /$ Sator.2016.17

Тарту 2016

Авторы: Ирина Ильина, Юлия Крашенинникова, Павел Лимеров, Людмила Лобанова, Светлана Низовцева, Алексей Рассыхаев, Анатолий Панюков, Галина Савельева,

Олег Уляшев

Редактор серии: Маре Кыйва

Редакторы-составители выпуска: Людмила Лобанова \& Николай Кузнецов

Оформление обложки: Анатолий Панюков \& Андрес Куперьянов

Верстка \& HTML: Диана Кахре

Печатное издание: ФОЛЬКЛОРИСТИКА КОМИ: исследования и материалы. SATOR 17. Тарту 2016

Составление, техническое оформление и печать книги осуществлены при поддержке Эстонского институционального исследовательского гранта 22-5 (Религиозные и нарративные аспекты фольклора).

Оформление электронного издания осуществлено при поддержке проекта ЕККМ14-344 “Расширение областей применения и представление эстонского языка, культуры и фольклора в электронных информационных средствах".

(с) EKM Teaduskirjastus / Научное издательство ЭЛМ

(c) Авторы

(с) Анатолий Панюков \& Андрес Куперьянов 